\title{
MENTORIAUS VEIKLOS RAIŠKOS REALIJOS IR PERSPEKTYVOS: LIETUVOS POLICIJOS MOKYKLOS ATVEJO ANALIZE்
}

\author{
Tomas Lukošius, Profesiniu igūdžiu valdybos trečiojo skyriaus vyriausiasis specialistas \\ Lietuvos policijos mokykla, \\ Dr. Gitana Tolutiené \\ Klaipédos universitetas \\ DOI: https://doi.org/10.52320/svv.v0iVI.197
}

\begin{abstract}
Anotacija
Straipsnio pirmoji dalis - teorinè, skirta išanalizuoti mentoriaus veiklos teorines prielaidas, atskleidžiant mentorystės ir mentoriaus sampratą, mentorystès formas, mentoriaus veiklos ypatumus, reikalingas savybes, veiklos funkcijas ir kt. Antroje - empirineje straipsnio dalyje kiekybiniu tyrimu siekiama atskleisti mentoriaus veiklos galimybes, raišką ir perspektyvą veiklos Lietuvos policijos mokykloje aspektu. Tyrimu nustatytas respondentų požiūris ị mentorystės svarbą statutinèje valstybès tarnyboje, jos tendencijos ir ypatumai. Šiame straipsnyje pristatomas tyrimas yra aktualus, nes nuo mentoriaus kompetencijų ir gebėjimų didžia dalimi priklauso, ar būsimasis pareigūnas įsitvirtins Lietuvos policijos mokykloje. Straipsnio naujumą ir praktinị reikšmingumą atskleidžia atliktas įstaigoje tarnaujančių pareigūnų požiūrio i mentorystę tyrimas. Vieno atvejo tyrimas padèjo nustatyti ir išskirti pagrindinius mentoriaus veiklos Lietuvos policijos mokykloje elementus ir formalios mentorystès galimybes, siekiant ją įdiegti šioje organizacijoje. Pagrindiniai teorinio ir empirinio tyrimų rezultatai pagrindžia, jog Lietuvos policijos mokykloje formalios mentorystės igyvendinimas vyks sėkmingai, jeigu sudaromos sąlygos sistemingam mentorių profesionalumo tobulinimui, yra pozityvus organizacijos vadovų požiūris į darbuotojų mokymą ir yra žmonès, gebantys ir pageidaujantys tapti mentoriais.
\end{abstract}

Pagrindiniai žodžiai: mentorystè, mentorius, proteguojamas asmuo, Lietuvos policijos mokykla.

\section{Ivadas}

Temos aktualumas. Siekti aukštesnių veiklos rezultatų, profesionalumo tampa neịmanoma be kolegų profesinès paramos, pagalbos. Mentorystė suvokiama kaip asmeninio tobulëjimo skatinimas, kuris pagrịstas abipusiais santykiais tarp tam tikroje srityje aukštesnę kvalifikaciją, kompetencijas turinčio darbuotojo (mentoriaus) bei mažiau patyrusio (proteguojamo) asmens (Benson, Scales, Hamilton ir Semsa, 2012).

Nepaisant to, kad visame pasaulyje sparčiai populiarėjančios mentorystės programos, modeliai diegiami pažangiose kompanijose, valstybès tarnyboje, ypač statutinèse organizacijose, iškyla problemų, sunkumų tai taikant bei randant tikrajj savo komandos ir organizacijos potencialą. Aukštos kvalifikacijos (kompetencijų) darbuotojai nesugeba (nepageidauja) perteikti turimos patirties mažiau patyrusiems. Vadovams trūksta žinių apie mentorystę kaip žmogiškųjų išteklių vystymo priemonę, kuri orientuota ị profesionalų bei asmeninį darbuotojų tobulejjimą. Lietuvos policijos mokykloje nèra iš anksto numatytų planų, tenkinančių konkrečius asmenybės augimo poreikius bei padedančių pilnai atskleisti turimą policijos pareigūnų ar kitų darbuotojų potencialą. Mentoriaus vaidmuo Lietuvos policijos mokykloje - padėti aukštųjų mokyklų studentams, kursantams ir pradedantiems dirbti pareigūnams igyti praktinio darbo gebėjimų, vadovauti jų mokomajai praktikai, padèti pasirengti tarnybai. Toks abipusis bendradarbiavimas yra naudingas visiems - organizacijai, mentoriui, proteguojamam asmeniui. Tai vienas ekonomiškiausių būdų, keliant darbuotojų ekspertiškumo lygị ir formuojant specialistų nuostatas, ugdant talentingus darbuotojus, juos motyvuojant bei išlaikant. Pagrindinis mentoriaus ir jo proteguojamo asmens santykių principas - galimybe abiems pusèms mokytis ir tobulèti.

Temos ištirtumas. Lietuvoje ir užsienyje galima aptikti daugybę mokslinių, publicistinių leidinių bei mokslo tyrimų, skirtų mentorystès reiškiniui, jos modelių analizei, mentoriaus veiklos funkcijų, kompetencijų aprašymui ir kt. Tačiau tiek Lietuvoje, tiek ir užsienio šalyse akivaizdžiai stokojama tyrimų, skirtų formalios mentorystės igyvendinimo galimybėms, formalaus mentoriaus veiklos sritims, jo nuostatų, elgsenos analizei, nes beveik visi tyrimai skirti mokytojų rengimui.

Mentorystė analizuojama ịvairių organizacijų veiklos kontekste. Benson'as ir kt. (2012) savo teorinemis j̨žvalgomis ir empiriniais tyrimais pagrindè mentorystę bei mentoriaus veiklos modelius. Duck'as (2014) mentorystę analizavo kaip priemonę, padedančią organizacijai palaikyti gerus 
darbuotojų tarpusavio santykius. Elliot'as ir Michalic'as (2014) mentorystès igyvendinimą izžvelgia kaip prevencinę priemonę. Green ir Sholes (2014) i mentorystę žvelgia kaip ì priemonę, padedančią išlikti ịtampos pilnoje darbo aplinkoje. Merrick (2014) mentorystę analizavo kaip organizacijos sèkmès pagrindinị veiksnị. Petrin $(2013 ; 2014)$ mentorystę prilygina verslo strategijai ir pateikia mentoriaus veiklos priemones. Shea (2013) atskleidė mentorystès organizavimo pagrindinius etapus, principus ir kt. Iš mokslinès literatūros ir atliktų tyrimų apžvalgos akivaizdžiai matyti mentorystės kaip socialinio reiškinio įvairové, jos igyvendinimas įvairiose organizacijose, mentorystès kaip paramos, pagalbos kitam darbuotojui esmé.

Šiame straipsnyje analizuojama problema: kokios yra mentoriaus veiklos raiškos galimybès Lietuvos policijos mokykloje?

Tyrimo objektas - mentorystès raiška Lietuvos policijos mokykloje.

Tyrimo tikslas - išanalizuoti mentoriaus veiklą ir pagrịsti mentorystės raiškos galimybes Lietuvos policijos mokykloje.

Tyrimo uždaviniai: 1) išanalizuoti mentoriaus veiklos teorines prielaidas, atskleidžiant mentorystès ir mentoriaus sampratą; 2) ištirti respondentų požiūrị i mentoriaus veiklos raiškos Lietuvos policijos mokykloje realijas ir perspektyvą.

Tyrimo metodai: mokslinès literatūros analizè, siekiant išanalizuoti mentorystès ir mentoriaus sampratą, mentorystès formas, mentoriaus veiklos ypatumus, reikalingas savybes ir veiklos funkcijas; anketinè apklausa, siekiant ištirti respondentų požiūrį i mentorystės svarbą ir poreiki Lietuvos policijos mokykloje, mentoriaus vaidmeni, funkcijas, kompetencijas ir kt.

\section{Mentorystės ir mentoriaus sampratų apžvalga}

Šiuolaikinis mentorystės modelis yra atėjęs iš Vakarų Europos šalių, kuris ypač sėkmingai buvo taikomas verslo srityje. Šių dienų kontekste mentorystė apibūdinama kaip turinčio patirti (angl. mentor) ir neturinčio arba turinčio nedidelę patirti asmens (angl. mentee) tarpusavio santykiai, pagalba, parama mokantis, integruojantis ị profesinès veiklos pasauli (Erich, Hansford ir Tennet, 2014). Galima teigti, jog mentoryste organizacijoje reiškia savanoriškus pradedančio veiklą ir turinčio veiklos patirti asmens santykius, padedančius tobulèti profesinèje veikloje, užtikrinančius profesinę integraciją, asmens karjerą. Mentorystès samprata atskleidžia ịvairius šios socialinès praktikos aspektus. Vieni (Houde, 2010 ir kt.) pabrèžia mentorystės tikslus ir mokymosi svarbą, kiti (Guay, 2012 ir kt.) - jos naudą, tačiau visais atvejais sutariama, kad mentorystė yra abipuse pagarba grịsti santykiai tarp turinčio patirties, pripažinto ir patikimo asmens (mentoriaus) bei jaunesnio ir neturinčio arba turinčio nedidelę patirti proteguojamo asmens. Šie abipusiai santykiai leidžia proteguojamam asmeniui konstruoti profesinį identitetą, sulaukti pagalbos vystant savo karjerą bei sèkmingai pereiti iš vieno karjeros etapo ị kitą (Guay, 2012).

Mentorystès misiją sudaro pagrindiniai elementai: savanorystè, savipagalba, mokymas, bendražmogiškosios vertybès, bendravimas. Svarbu, kad būtų teigiamas organizacijos vadovų požiūris ị mentorystès reiškini ir užtikrinta parama jos ịgyvendinimui (Rhodes, Reddy, Roffman ir Grossman, 2015). Ten pat pastebima, kad skirtingose organizacijose kai kurie mentorystès tikslai dažnai panašūs ar identiški: karjeros planavimas ir vystymas; profesine integracija; vadovavimo gebėjimų ugdymas; ịsidarbinimo galimybių plètojimas; perèjimas ị aktyvią profesinę veiklą; darbuotojų kaitos valdymas; kompetencijų vystymas; parama, pagalba jauniems profesionalams; parama, pagalba veikiant.

Mentorystès nauda organizacijai reiškiasi tobulèjančia profesine ir asmenine darbuotojų kompetencija. Dažnai tiek privačios, tiek valstybinès organizacijos susiduria su kvalifikuotu darbuotojų trūkumu. Mentoriai gali užpildyti šią spragą, apmokydami darbuotojus. Tokiu būdu darbuotojai labiau issitraukia ir ịsipareigoja organizacijai. Mentorystè veikia kaip efektyvi darbuotojų tobulejjimo ir skatinimo priemonè, neturinti papildomų kaštų. Ji padeda organizacijoje sumažinti žmonių kaitą. Jei organizacija turi daugiau lyderių, tai reiškia, jog ji turi didesnị rezervą kvalifikuotų darbuotojų, galinčių prisiimti atsakomybę dèl organizacijos veiklos (http://pvpa.lt/veikla/mentoryste).

Teigiama, kad žinias galima skirstyti bent ị dvi rūšis: pirmosios yra sąmoningos, jos surašytos knygose ir lengvai perduodamos; antrosios yra nesąmoningos, patirtinès, jos unikalios, sukauptos 
žmogaus. Patirtinės žinios yra profesionalo ilgametė kompetencija, kuria remdamasis jis žino, kaip geriausia elgtis tam tikroje situacijoje. Profesionalu netampama mokykloje ar studijose. Juo tampama praktikuojant pasirinktą veiklą (profesiją) - darant, eksperimentuojant, méginant (neretai klystant) ir nuolat mokantis. Profesionalumas išlavinamas praktikos ir mokymo/si su mentoriumi metu. Tačiau mentorius turi gebėti mokyti. Šia prasme mentorystė teikia unikalią progą leisti mažiau patirties, kompetencijų turinčiam asmeniui pasinaudoti turimomis mentoriaus kompetencijomis, žiniomis, patirtimi (Houde, 2010). Patirtinė kompetencija išsivysto, kai žmogus pats atranda sprendimą - taip jis perima labiau patyrusio darbuotojo kompetenciją. Besimokantieji nori patirti ir išmokti patys. Tuo mentoryste ir vadovaujasi.

Organizacijose mentorystės pobūdis yra skirtingas. Išskiriama neformali ir formali mentoryste (Guay, 2012). Lietuvoje ir užsienyje dažniausiai stebima neformalios mentorystès raiška, kai naujai priimtam i darbą asmeniui, neturinčiam profesinès veiklos patirties arba nedaug jos turintiems, savanoriškai padeda kolegos. Tačiau mentorystès samprata gali būti konkretinama, lyginant su kitais paramos, pagalbos reiškiniais, pavyzdžiui, ugdomuoju vadovavimu (angl. coaching) ar supervizija (angl. supervision). Daugelyje organizacinių ugdomasis vadovavimas ir mentorystė (angl. mentoring) naudojami kartu. Nors savo tikslais panašios, bet šios sąvokos turi esminių skirtumų. Taikant ugdomaji vadovavimą ir mentorystę abiem atvejais remiamasi parama, pagalba darbuotojams. Todèl kartais sunku atskirti vieno ar kito reiškinio ribas, ugdomojo vadovavimo specialisto bei mentoriaus vaidmenu skirtumus, nes pats paramos, pagalbos procesas yra svarbesnis nei tikslas.

Mentorystė yra visaapimantis procesas, kurio metu gali būti pasitelkiamas tiek ugdomasis vadovavimas, tiek kitos tobulejimo formos, kurių bene svarbiausia - paties mentoriaus dalijimasis turima patirtimi ir žiniomis (Hawkins, 2013). Mentorius turi būti autoritetu besimokančiajam, tuo tarpu ugdomajame vadovavime jų santykis pasiskirsto lygiavertiškai (Petrin, 2014). Mentoriaus atsakomybė proteguojamam asmeniui yra didesnè. Tam, kad padètų kitam, geras mentorius privalo gerai pažinti save ir būti specialistas tos srities, kuriai atstovauja jo proteguojamas asmuo (Hezleet ir Gibson, 2015).

Žodynuose angliškas terminas „supervision“ verčiamas ị lietuvių kalbą kaip „vadovavimas“, „priežiūra“, „prižiūrējimas“ (kito žmogaus veiksmų ar darbo). Viena iš sampratų siejama su priežiūra labiau patyrusio asmens, jo pagalba mažiau patyrusiajam (Cloud ir Townsend, 2013). Supervizija Lietuvos policijos mokyklos kontekste - ne tik profesinių santykių konsultavimas, kurio metu kuriamas tarpasmeninis santykis tarp labiau patyrusio pareigūno (mentoriaus) ir naujai priimto pareigūno (proteguojamo asmens), bet ir mokymosi bei kvalifikacijos kèlimo procesas. Šis procesas išsiskiria iš kitu profesinio konsultavimo ar kvalifikacijos tobulinimo formų tuo, kad skirtingai nuo mokymų, supervizijoje nèra iš anksto numatytų temų, teorijų, standartinių programų ar metodų. O santykis formuojasi ten, kur susitinka dviejų žmonių asmeninès ribos. Todèl ribų, jų suvokimo, ịsivertinimo, išsaugojimo, galimo pažeidimo ar kaip tik saugumo suteikimo tema mentorystès atveju itin aktuali (Cloud ir ir Townsend, 2013).

Kiekvienas žmogus asmeninę erdvę suvokia savaip ir ribas pajunta dažniausiai tada, kai jos yra pažeidžiamos. Susierzinimas, padidejusi įtampa, staiga pasikeitusi nuotaika, nejaukumas, apėmęs bejègiškumas, pyktis - visa tai signalai, kad asmeninès ribos pažeistos. Supervizijoje mentoriaujantis pareigūnas turi galimybę elgtis kitaip negu ịprasta, supervizoriaus padedamas gali eksperimentuoti su savo jausmais ir poelgiais bei savo asmeninèmis ribomis. Tai vienas iš teigiamų supervizijos aspektų, patirčių, leidžiančių judèti ị priekị. Pagrindinis dalykas - įvertinti, kad pasipriešinimas yra proceso sudètinè dalis, kuri reiškia judèjimą i prieki ir keitimosi pradžią (http://www.supervizija.lt/lt/asmenines-ribos).

Specialus pasirengimas mentorystei ir pedagoginè kvalifikacinè kategorija turi esminę įtaką gilesniam, profesionalesniam mentoriaus požiūriui $\mathfrak{i}$ atskirų kompetencijų ir jų komponentų svarbą. Mentoriaus profesinès veiklos lauke išryškèja visos mentoriaus kompetencijos, tačiau vienos ryškiau, kitos mažiau. Profesinès praktikos metu labiausiai atsiskleidžia ugdančiajam santykiui aktualios mentoriaus asmeninès, socialinès, vadybinès ir didaktinès kompetencijų apraiškos, o mažiau mentoriaus darbo specifiką lemiančios mentoriaus informavimo ir komunikavimo, vertinimo, ekspertavimo, refleksijos skatinimo, profesinès praktikos organizavimo ir praktikos refleksijos kompetencijos (http://avmi.lt/ementoryste/tema/mentoriu-ir-ugdytiniu-charakteristikos). 
Efektyvaus mentoriaus vertybė yra noras ugdyti kitą asmenį. Tai aiškus pedagoginio pašaukimo atspalvis, todèl nenuostabu, kad mentoriui priskiriamos ịvairios pedagogui būtinos kompetencijos. Išskiriamos tokios svarbiausios mentorystės funkcijos: susitarimas, ịvertinimas, pagalba, vadovavimas. Kaip esminis mentoriaus gebejjimas įžvelgiamas bendravimas, kadangi didelè dalis mentoriaus laiko tenka bendravimo veiklai. Atkreiptinas demesys $\mathfrak{i}$ tai, kaip mentorius išlaiko sunkumus ir priima iššūkius, padrąsina žmones pačius galvoti, nesprendžia už juos jų problemų, bet padrąsina juos pačius ieškoti galimų sprendimų (http://toastmasters.lt/mentoryste).

Apibendrinant galima teigti, kad mentorystès samprata ir pagrindiniai bruožai atskleidžia šios socialinès praktikos aspektus. Vieni jų akcentuoja mentorystès tikslus ir mokymosi svarbą, kiti mentorystès naudą. Tačiau visais atvejais pabrèžiama, kad mentorystė - tai abipuse pagarba grịsti savanoriški santykiai tarp mentoriaus ir globojamo asmens. Mentoryste yra mokymo būdas, kuris sujungia daugeli kitų mokymo formų. Mentorius gali naudoti ugdomajji vadovavimą ar superviziją kaip efektyviausius mokymo būdus. Savybès, kuriomis mentorius turi pasižymèti - tai kompetencija, pagarba, lankstumas, pasitikèjimas savimi ir proteguojamu asmeniu, suinteresuotumas padèti, būti pavyzdžiu. Formali mentorystė dažniausiai reikalinga perejjimo iš vieno karjeros etapo i kitą arba pereinant $i$ aukštesni kompetencijų, profesionalumo lygmenị. Lyginant su neformalia mentoryste, toks stuktūrizuotas procesas suteikia žymiai daugiau naudos visiems jo dalyviams.

\section{Mentoriaus veiklos raiškos realijų ir perspektyvos Lietuvos policijos mokykloje tyrimas}

\subsection{Tyrimo organizavimas, metodologija, metodai ir dalyviai}

Tyrimo uždaviniai: 1) išanalizuoti respondentų požiūrị $\mathfrak{i}$ tarnybą, darbo aplinką ir motyvuojančias priemones; 2) ištirti respondentų požiūrị i mentorystès raišką ir poreiki Lietuvos policijos mokykloje, atskleidžiant mentorystès svarbą (itaką) mentoriaus veiklos perspektyvai.

Tyrimo metodas - internetinè apklausa (anketavimas). Anketa Lietuvos policijos mokyklos darbuotojams išplatinta tarnybiniu elektroniniu paštu, naudojant „Google forms“ įrankį. Taip pat atsižvelgta ị šio metodo žemas finansines ir laiko sąnaudas, aukštą respondentų pasiekiamumą ir grąžinimo lygị.

Matematiniai statistiniai tyrimo metodai. Gautų duomenų analizei atlikti naudota specializuota statistine kompiuterine programine įranga SPSS (23.0 versija). Pagrindinis šio programinio paketo privalumas - didelis šiuolaikinių statistinių analizès metodų pasirinkimas bei duomenų analizès rezultatų vizualizavimo priemonių (duomenų pateikimo lentelių, diagramų) įvairovè, lengvai ịvaldoma dialoginè sąsaja (Bekešienè, 2015). Naudotos procedūros: aprašomosios statistikos dažnių skaičiavimo procedūra. Apskaičiuoti respondentų atsakymų ị klausimus procentai, vertinimų vidurkiai. Dispersija - - reiškinių skirtumas (nuokrypių) nuo vidurkio kvadratų vidurkis (duomenų išsisklaidymas). Minimali ir maksimali vertinimo reikšmė. Priklausomybès tarp vardinių ir rangų skalès kintamųjų analizei SPSS panaudotos dvimatès požymių dažnių lentelès (Crosstabs). Pasirinktas plačiausiai taikomas iš neparametrinių kriterijų Chi-kvadrato $(\chi 2)$ kriterijus, kuris parodo, ar empirinio ir teorinio skirstinių skirtumas yra reikšmingas. Gauti tyrimo duomenys susisteminti ir išanalizuoti bei tarpusavyje palyginti. Chi-kvadrato kriterijus taikytas ieškant statistiškai reikšmingu atsakymų skirtumų i klausimus pagal respondentų sociodemografinius duomenis. Spearman's koreliacijos koeficientas taikytas ieškant ryšio tarp kintamujų, matuojamų rangine skale. Tyrimo rezultatų analizèje pateikiamos ir detalizuojamos tik reikšmingos porinès koreliacijos.

Tyrimo duomenu rinkimo instrumentas - anketa (klausimynas), sudaryta vadovaujantis literatūros apžvalga bei kitų tyrèjų (Vileikienè, 2018 ir kt.) atliktais tyrimais. Anketos klausimai (atsakymų i juos variantai) parengti pagal nominalinę skalę, kurios duomenys ne tik suskirstomi i tam tikras kategorijas, bet tos kategorijos turi savo natūralią didejjimo tvarką. Klausimai anketoje suskirstyti $\mathfrak{i}$ tris dalis (blokus). Pirmoji dalis Bendra informacija, kurios tikslas - nustatyti respondentų amžių, išsilavinimą, sąsajas su mentoryste, užimamas pareigas ir pan. Šie duomenys leidžia konkrečiau ịvardinti respondentų darbo patirtị ir susiformavusią pasaulèžiūrą bei nuomonę apie tarnybą. Antroji dalis Tarnybos, darbo aplinkos ir motyvaciniu priemoniu vertinimas, kurioje siekiama atskleisti ryši tarp respondentų požiūrio ir sėkmingos mentoriaus veiklos. Trečioji dalis Mentorystès raiška ir 
poreikis, kurioje siekiama nustatyti respondentų požiūrị ì mentoriavimą, mentoriaus funkcijas, savybes, geriausiai atitinkančias darbą Lietuvos policijos mokykloje, bei išsiaiškinti mentoriavimo perspektyvas Lietuvos policijos mokykloje. Anketos pabaigoje pateikiami keturi atviri klausimai bei suteikiama galimybė pateikti savo pastabas ir pasiūlymus, ịvardinti mentoriaus veiklos privalumus ir trūkumus.

Validumas. Validumas suprantamas kaip metodikų kokybės kriterijus - jų tinkamumas, adekvatumas. Išorinis tyrimo instrumento validumas susijęs su imties sudarymu. Siekiant nustatyti klausimyno validumą, SPSS programa buvo apskaičiuotas bendras jo patikimumo koeficientas. Klausimyno skalès vidinis nuoseklumas (suderintumas) patikrintas naudojant Cronbacho alfa koeficientą. Panaudotas metodas yra dažniausiai naudojamas statistinis įvertinimas, kurio nustatyta reikšmė 0,615 rodo pakankamą instrumento vidinį nuoseklumą. Todèl galima teigti, kad klausimynas yra patikimas ir tinkamas naudoti, siekant pagrịsti gautus duomenis ir išvadas, kurios taikytinos tik tirtos organizacijos atžvilgiu.

Tyrimo organizavimas ir dalyviai. Prašymai užpildyti anketą buvo išsiųsti 144 asmenims. Anketoje nurodoma tyrimo tema ir tikslas, pildymo instrukcija, taip pat akcentuojamas anketą užpildžiusio respondento anonimiškumas. Anketu grįžtamumas - 92,4 proc., t. y. grįžo 133 anketos, tačiau apdorojimui tinkamomis atrinktos 126 anketos. Tyrimo metu gauti duomenys buvo sisteminami, grupuojami ir pristatomi grafiškai (lentelèse, paveiksluose) bei aprašomi. Tokia tyrimo imtis leido pakankamai reprezentatyviai pristatyti tyrimo problematiką. Šiam tyrimui respondentai buvo atrenkami patogiosios atrankos būdu.

Tyrimo etika. Tyrimas vykdytas, nepažeidžiant respondentų teisių ir laikantis pagrindinių tyrimo etikos principų: savanoriškumo, informacijos etikos klausimais suteikimo, konfidencialumo ir anonimiškumo.

\subsection{Pagrindiniai tyrimo rezultatai ir jų analizė}

Respondentai pasirinkti atsitiktinai iš Lietuvos policijos mokyklos darbuotojų (26 proc. respondentų, dirbantys mokykloje ir 74 proc. - nutolusiose darbo vietose). Svarbu pastebėti, jog apskrities vyriausiuose policijos komisariatuose mokymus vykdantys respondentai betarpiškai bendrauja su policijos pareigūnais ir jų požiūris ị tarnybą ir mentorystę gali atspindèti bendrą požiūrị.

Apklausoje dalyvavo 126 respondentai, kurių amžius - nuo 18 iki 65 metų, tačiau dominuoja 41 - 50 metų amžiaus grupé (42 proc. apklaustujų), kaip ir grupé, turinti aukštaji universitetini išsilavinimą (76 proc. apklaustųjų). 43,3 proc. apklaustųų turi daugiau kaip 20 metų darbo stažą, 20 proc. - 16 - 20 metų darbinę patirtị. Nustatyta, kad net 82,7 proc. didžiausią darbo stažą turinti grupé turi aukštaji universitetinį išsilavinimą. Tokie rezultatai rodo, kad atsižvelgiant i gautus rodiklius ir galiojančias teisės aktų nuostatas, 4-6 metų laikotarpiu tarnybą gali palikti apie pusė patyrusių ir išsilavinusių pareigūnų. 83,3 proc. respondentų pažymėjo esantys pareigūnais (statutiniais valstybès tarnautojais). Šie atsakymai pagrindžia tinkamą tyrimo grupès pasirinkimą, nes esminis policijos sistemos specifiškumas - joje tarnaujantys pareigūnai, todèl tyrimo metu gauti duomenys ir jų interpretavimo rezultatai galès būti panaudoti ir kitose policijos įstaigose.

Analizuojant respondentų atsakymus i klausimą, kokiame padalinyje jie dirba, 50 proc. apklaustujų pažymėjo atsakymą „kita“ (1 pav.). Tai rodo, jog pusės respondentų pagrindinès funkcijos yra tiesiogiai susijusios su mokymo proceso vykdymu. 


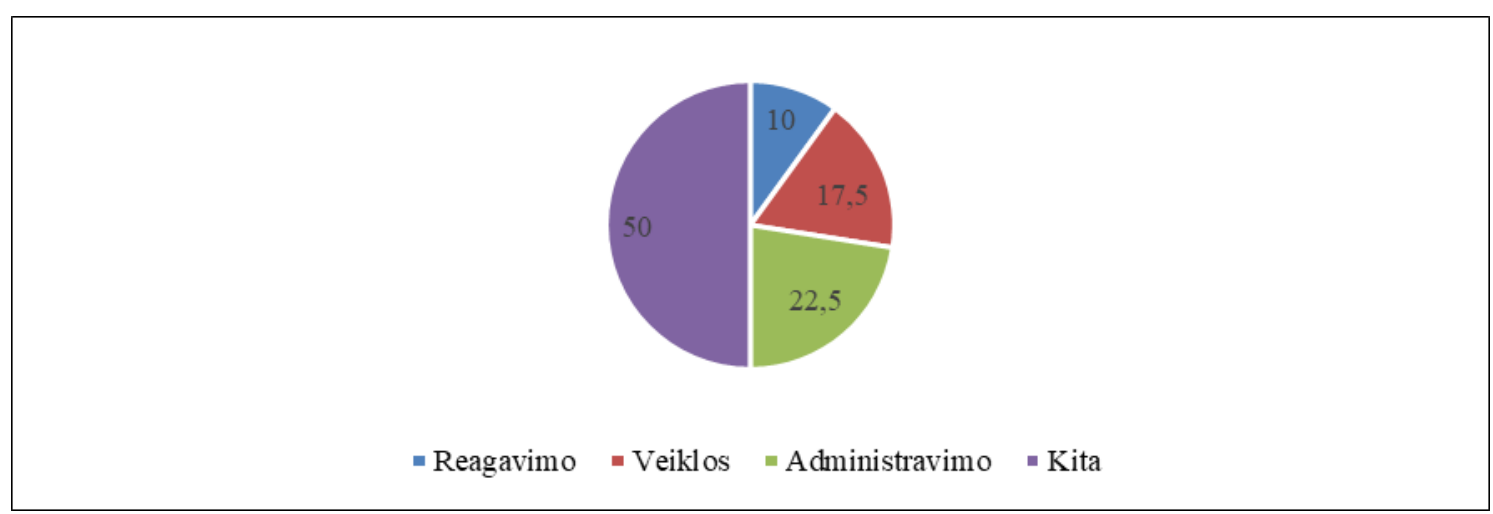

1 pav. Apklausos dalyvių darbo padalinys

Šaltinis: sudarytas autorių pagal atlikto tyrimo duomenis

Taip pat pagrịsti teiginiai, kad i policijos sistemą patenkama įvairiais būdais turint skirtingą išsilavinimą, nes net 30 proc. respondentų turi ne policijos krypties, nespecializuotą išsilavinimą ir 14 proc. respondentų specializuotas išsilavinimas apsiriboja 6-12 savaičių trukmès kursais.

Iš apibendrintos duomenų analizès aiškejja, jog policijos sistemoje yra pakankamai darbuotojų, turinčių išsilavinimą ir patirtį, kurie galètų padèti mažiau patyrusiems darbuotojams. Tačiau norint išlaikyti vertingą patirti turintị personalą, svarbu parinkti tinkamas motyvavimo priemones.

Šioje tyrimo dalyje, aiškinantis pareigūnų požiūrị i tarnybą, aplinką ir motyvuojančias priemones, užduotas klausimas Kodèl pasirinkote darba šioje tarnyboje? Dominuoja atsakymai: norejjau dirbti bütent toki darba - 45 proc. (ši populiariausią atsakymą pasirinko 60 poc. respondentų, kurių stažas 11 - 15 metų; 58,3 proc. respondentų, kurių stažas 16 - 20 metų; 46,2 proc. respondentų, kurių stažas virš 20 metų bei taip susikloste aplinkybès - 18,3 proc.). Tyrimo metu nustatyta, kad 66,7 proc. pasirinkusiujų atsakymą manau, jog tai kilni profesija - darbo stažas tarnyboje yra iki 1 metų. Likusių 33,3 proc. šioje grupeje pasirinkimą motyvuoja galimybè padaryti karjerą. Buvo lengva įsidarbinti - 31,7 proc., tuo tarpu ši atsakymo variantą rinkosi tik 9,6 proc. pareigūnų, kurių darbo stažas yra virš 20 metų (1 lentelè). Kadangi išsiskiria skirtingu laikotarpiu tarnybą pasirinkusių respondentų motyvacija, galima daryti prielaidą, kad darbuotojų požiūris ì procesus tarnyboje yra reikšmingas veiksnys jų tolimesnei veiklos eigai (mentorystei).

1 lentelè. Tarnybos pasirinkimas ir stažas tarnyboje

\begin{tabular}{|c|c|c|c|c|c|c|c|}
\hline \multirow{2}{*}{ Duomenys pateikti procentais } & \multirow{2}{*}{ Duomenys pateikti procentais } & \multicolumn{6}{|c|}{ Stažas tarnyboje } \\
\hline & & Iki metų & $\begin{array}{l}1-5 \\
\text { metai }\end{array}$ & $\begin{array}{l}6-10 \\
\text { metų }\end{array}$ & $\begin{array}{l}11-15 \\
\text { metur }\end{array}$ & $\begin{array}{l}16-20 \\
\text { metur }\end{array}$ & Virš 20 metų \\
\hline \multirow{10}{*}{ 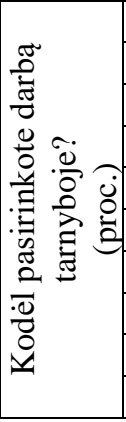 } & Lengva ịsidarbinti & & 15,8 & 8,3 & 20,0 & 4,2 & 5,8 \\
\hline & Galimybė padaryti karjerą & 33,3 & & 8,3 & 10,0 & 4,2 & 5,8 \\
\hline & Nebuvo galimybių susirasti darbą & - & - & - & - & 4,2 & - \\
\hline & Norèjau dirbti būtent tokị darbą & - & 42,1 & 16,7 & 60,0 & 58,3 & 46,2 \\
\hline & Norèjau padèti žmonėms & - & & 16,7 & & 8,3 & 9,6 \\
\hline & Patarè ar pasiūlè artimieji & - & 10,5 & & & 4,2 & 9,6 \\
\hline & Taip susiklostė aplinkybès & - & 15,8 & 41,7 & 10,0 & 16,7 & 17,3 \\
\hline & Žadamos socialinės garantijos & - & - & - & - & - & 3,8 \\
\hline & Manau, tai kilni profesija & 66,7 & 5,3 & 8,3 & - & - & 1,9 \\
\hline & Kita & - & 10,5 & - & - & - & - \\
\hline
\end{tabular}

Šaltinis: sudarytas autorių pagal atlikto tyrimo duomenis

Respondentai, nurodydami, kokios priemonès juos galètų labiausiai motyvuoti darbui, dažniausiai rinkosi atsakymus: darbo užmokestis - 71 proc., geras psichologinis klimatas padalinyje 60,5 proc., stabilumas darbe - 58,9 proc., tinkamas darbo organizavimas bei darbo krūvio paskirstymas ir įdomus, patinkantis darbas - po 46 proc. Šie duomenys atitinka kitų tyrimų (Vileikienè, 2018 ir kt.) rezultatus ir išlieka pagrindiniais motyvais. Atsakymai i pastaruosius du klausimus leidžia daryti prielaidą, kad tinkamai parinkus motyvacines priemones Lietuvos policijos mokykloje, yra pakankamas skaičius pareigūnų, galinčių tapti mentoriais. 
Atsakydami ị klausimą apie sąsajas su mentoryste, net 72 proc. respondentų ịvardijo save kaip nesusijusị su šiuo procesu. Tačiau atsakydami ị klausimą, kuriame detalizuojama formali ir neformali mentoriaus veikla, tik 40 proc. respondentų nurode, kad mentoriumi nebuvo ( 2 pav.).

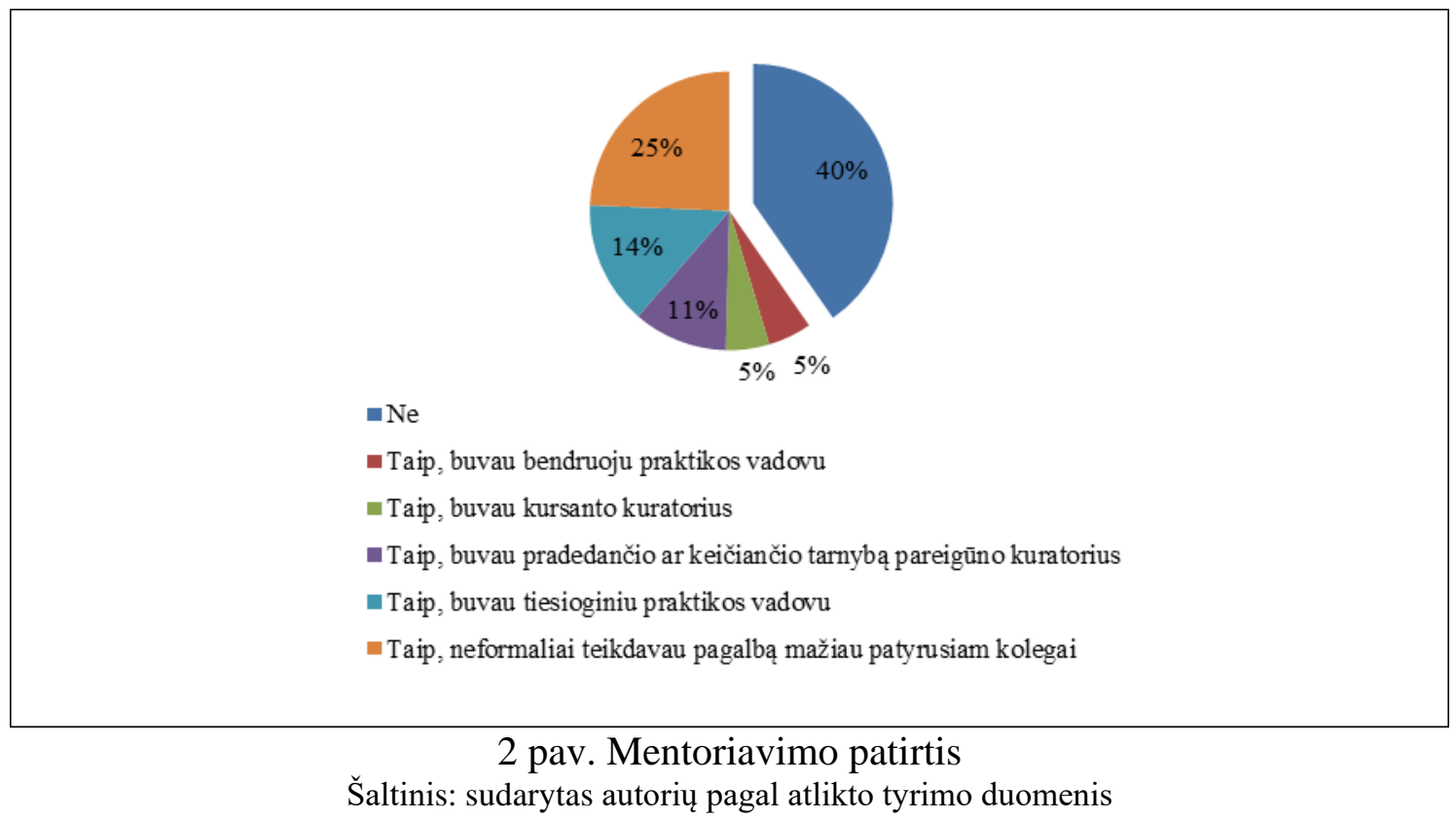

Kaip matyti (3 pav.), net 48 proc. respondentų teigia tarnyboje turèję mentorių.

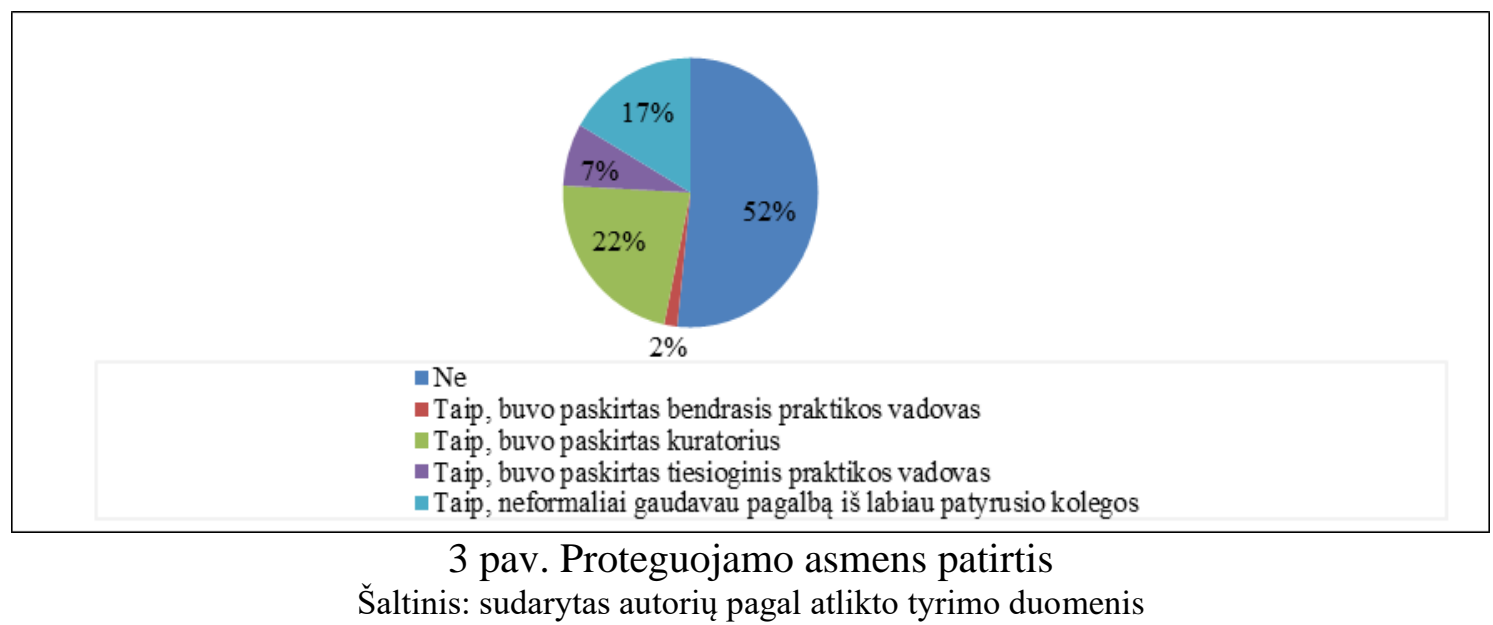

Atlikus kintamujų Ar Jums teko būti mentoriumi ir Mentorystès procesas - veiklos modeliavimas koreliacinę analizę, nustatyta tiesioginè koreliacija. Kadangi $\mathrm{p}=0,024<0,01$, tarp kintamujų yra statistiškai reikšmingas ryšys. Spearman'o koreliacijos koeficientas lygus 0,205 - ryšys tarp kintamųu yra silpnas $\left(\chi^{2}=5,585 ; \mathrm{df}=5 ; \mathrm{p}=0,349\right)$. Analizuojant respondentų, atsakiusių i abu klausimus, atsakymus, nustatyta: 94,1 proc. (pasirinkusių atsakymą Taip, buvau tiesioginiu praktikos vadovu), 100 proc. (pasirinkusiu atsakymą Taip, buvau bendruoju praktikos vadovu) ir 84,6 proc. respondentu (pasirinkusių atsakymą Taip, buvau pradedančio ar keičiančio tarnyba pareigūno kuratorius) nesieja šiuo metu Lietuvos policijos mokykloje vykstančio mentorystės proceso su veiklos modeliavimu. Veiklos modeliavimą dažniau rinkosi respondentai, kurie atsakè neturèję mentoriavimo patirties arba pagalbą teikè neformaliai. Remiantis gautais rezultatais, galima teigti, kad formali mentoryste Lietuvos policijos mokykloje nèra orientuota $\mathfrak{i}$ veiklos modeliavimą, o siejama su kursantų kuratoriaus ir bendrojo praktikos vadovo veiklomis.

52 proc. respondentu mentoriu rengimą policijos sistemoje vertina neigiamai, pasirinkdami atsakymus: Nežinojau, kad toks rengimas egzistuoja; esamo rengimo nepakanka ir kt., tačiau trečdalis tiriamujų pritaria mentoriaus pareigybès įvedimui (4 pav.). 


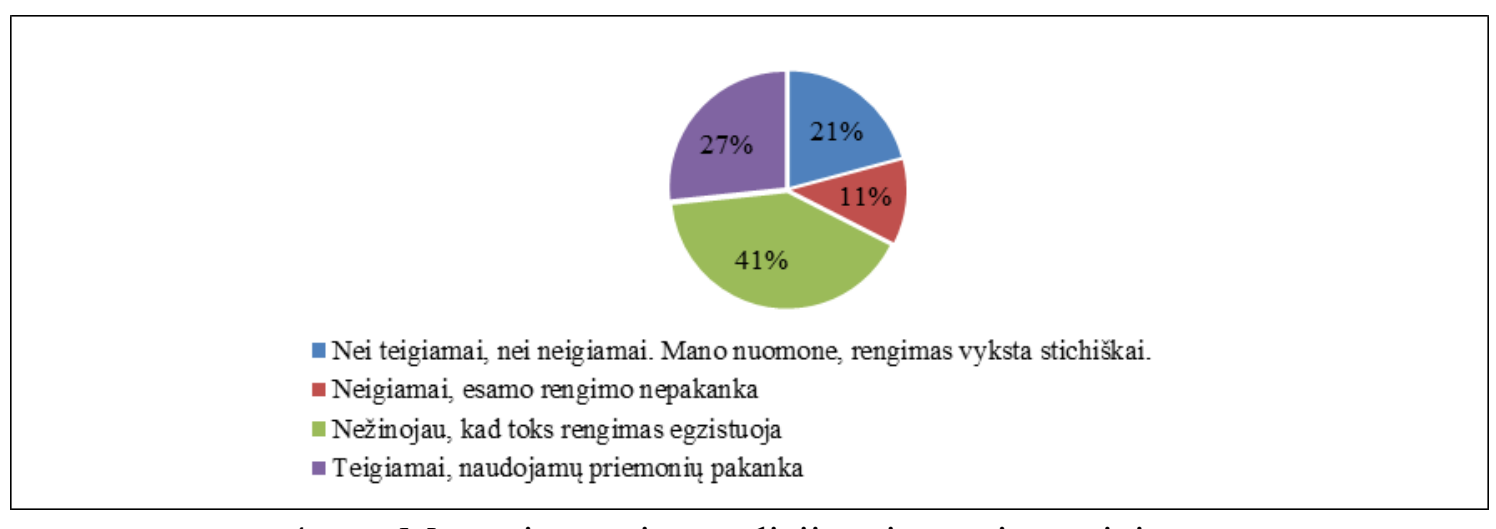

4 pav. Mentorių rengimo policijos sistemoje vertinimas

Šaltinis: sudarytas autorių pagal atlikto tyrimo duomenis

Atlikus kintamujų Ar tikslingas mentoriaus pareigybès įvedimas " ir Ka manote apie mentoriaus indèlį? koreliacinę analizę, nustatyta tiesioginè koreliacija. Kadangi $\mathrm{p}=0,000<0,05$, tarp kintamujų yra statistiškai reikšmingas ryšys. Spearman'o koreliacijos koeficientas lygus 0,474 - ryšys tarp kintamuju yra silpnas $\left(\chi^{2}=48,450 ; \mathrm{df}=8 ; \mathrm{p}=0,000\right)$. Analizuojant respondentu atsakymus ( 2 lentelè), nustatyta, $\mathrm{kad}$ 93,8 proc. atsakiusiųjų i abu klausimus mentoriaus indèlị laiko labai svarbiu. Kadangi didejjant pritarimui mentoriaus pareigybès ịvedimui, didèja mentoriaus indèlio svarba, todèl galima daryti prielaidą, kad teigiamas mentoriaus indèlis siejamas su formalios mentorystès perspektyva.

2 lentelè. Kintamujų Ar tikslingas mentoriaus pareigybès įvedimas? ir Ka manote apie mentoriaus indeli ? koreliacija

\begin{tabular}{|c|c|c|c|c|c|c|}
\hline \multirow{2}{*}{\multicolumn{2}{|c|}{ Duomenys pateikti procentais }} & \multicolumn{5}{|c|}{ Ką manote apie mentoriaus indèlį? } \\
\hline & & Labai svarbus & Svarbus & Patenkinamas & Nesvarbus & Visai nesvarbus \\
\hline \multirow{3}{*}{$\begin{array}{c}\text { Ar tikslingas mentoriaus pareigybès } \\
\text { ịvedimas? }\end{array}$} & Taip & 93,8 & 63,2 & 26,1 & 16,7 & - \\
\hline & $\mathrm{Ne}$ & & 5,3 & 21,7 & 50,0 & 100,0 \\
\hline & Nežinau & 6,3 & 31,6 & 52,2 & 33,3 & - \\
\hline
\end{tabular}

Šaltinis: sudarytas autorių pagal atlikto tyrimo duomenis

Atlikus kintamujų Ar tikslingas mentoriaus pareigybès įvedimas? ir Mentorystès procesas reguliavimas koreliacinę analizę, nustatyta tiesioginè koreliacija. Kadangi $p=0,012<0,05$, tarp kintamujų yra statistiškai reikšmingas ryšys. Spearman'o koreliacijos koeficientas lygus 0,230 - ryšys tarp kintamujų yra silpnas $\left(\chi^{2}=7,797 ; \mathrm{df}=2 ; \mathrm{p}=0,020\right)$. Analizuojant respondentų, atsakiusių i abu klausimus, atsakymus, nustatyta, kad 86,3 proc. nesieja šiuo metu Lietuvos policijos mokykloje vykstančio mentorystès proceso su reguliavimu. Reguliavimą dažniau rinkosi respondentai, kurie neigiamai žiūri į mentoriaus pareigybès ịvedimą. Kadangi kuo daugiau mentorystès raiška siejama su reguliavimu, tuo mažiau pritariama mentoriaus pareigybės įvedimui, todèl galima daryti prielaidą, jog įvestina mentoriaus pareigybė Lietuvos policijos mokykloje nebūtų orientuota ị veiklos reguliavimą.

Tik 9 proc. respondentų nuomone, mentorių indèlis ì policijos sistemos gerinimą, padedant jauniesiems policijos pareigūnams įsitvirtinti organizacijoje, yra nesvarbus ar visiškai nesvarbus (5 pav.). Atlikus kintamujų Ka manote apie mentoriaus indèli? ir Ar tikslingas mentoriaus pareigybès jvedimas? koreliacinę analizę, nustatyta tiesioginė koreliacija. Kadangi $\mathrm{p}=0,000<0,01$, tarp kintamuju yra statistiškai reikšmingas ryšys. Spearman'o koreliacijos koeficientas lygus 0,474 , - ryšys tarp kintamujų yra silpnas $\left(\chi^{2}=48,450 ; d f=8 ; p=0,000\right)$. 


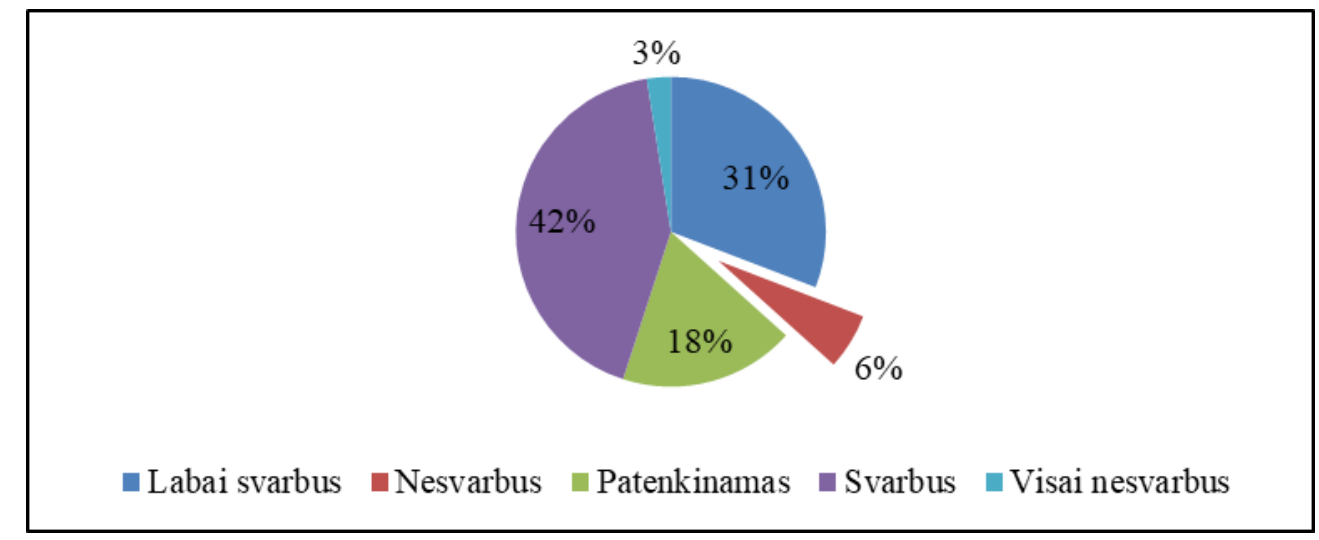

5 pav. Respondentų nuomonè apie mentorių indèlị ị policijos sistemos gerinimą Lietuvoje, padedant jauniems pareigūnams įsitvirtinti organizacijoje Šaltinis: sudarytas autorių pagal atlikto tyrimo duomenis

Respondentų nuomone, svarbiausia savybè, kuria turètų pasižymèti mentorius, yra komunikabilumas. Šią savybę išskyrė 55 proc. tiriamujų (6 pav.). Mažiau svarbiomis savybèmis laikomas lankstumas, gebejjimas vadovauti ir atvirumas.

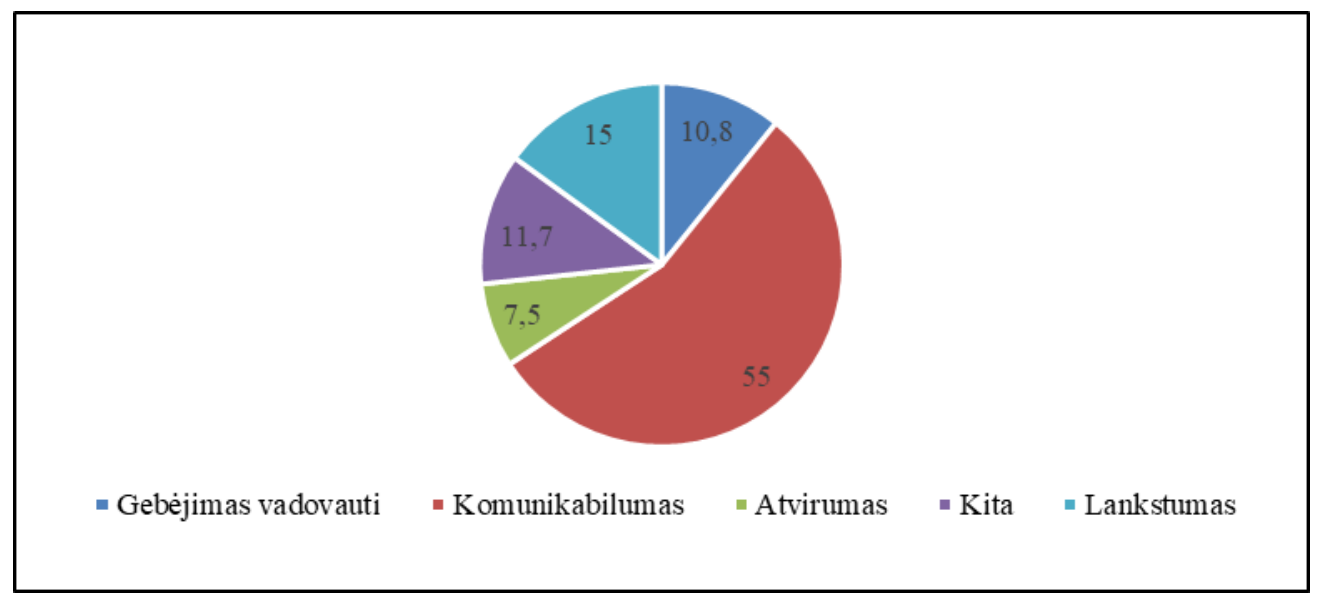

6 pav. Mentoriaus savybès

Šaltinis: sudarytas autoriu pagal atlikto tyrimo duomenis

Respondentai išskyrè gebėjimus, būtinus kompetentingam mentoriui: mokejjimas naudotis informacinių technologijų teikiamomis galimybėmis - 42,5 proc., komandinio darbo organizavimas 19,2 proc. ir gebèjimas rengti mokomąją medžiagą - 15 proc. ( 7 pav.).

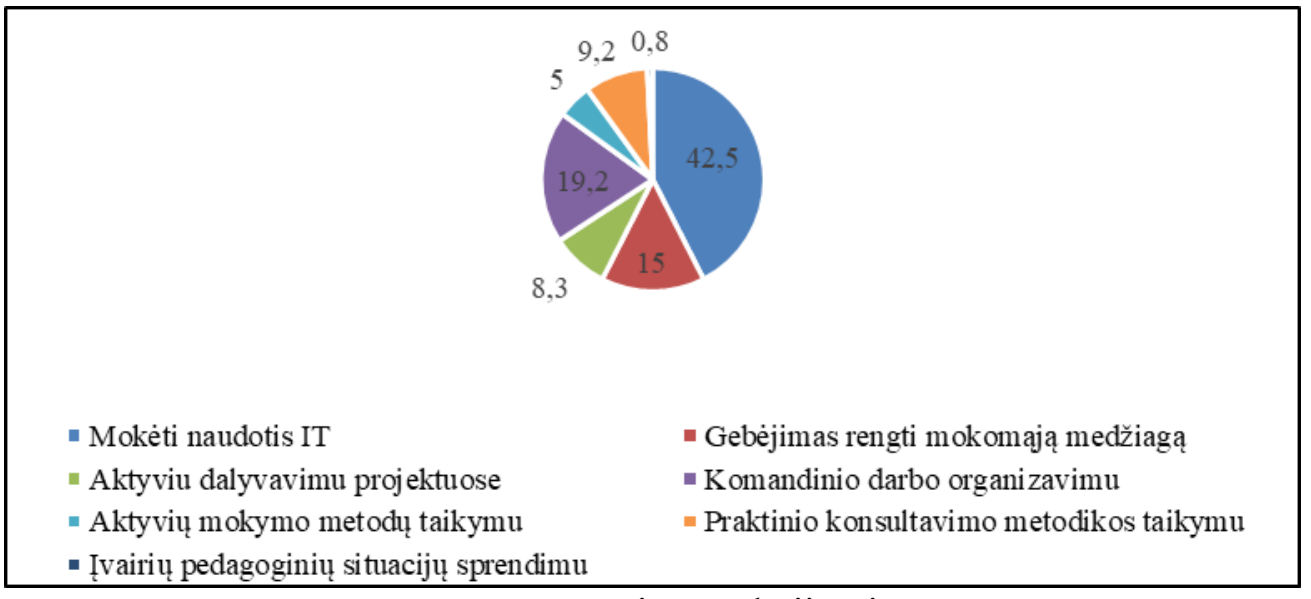

7 pav. Mentoriaus gebejjimai

Šaltinis: sudarytas autorių pagal atlikto tyrimo duomenis 
Po 44,2 proc. respondentų manymu, mentoriaus vaidmuo policijoje turètų būti įvardintas kaip konsultanto ir vadovo arba patarejo - 28,3 proc. (8 pav.).

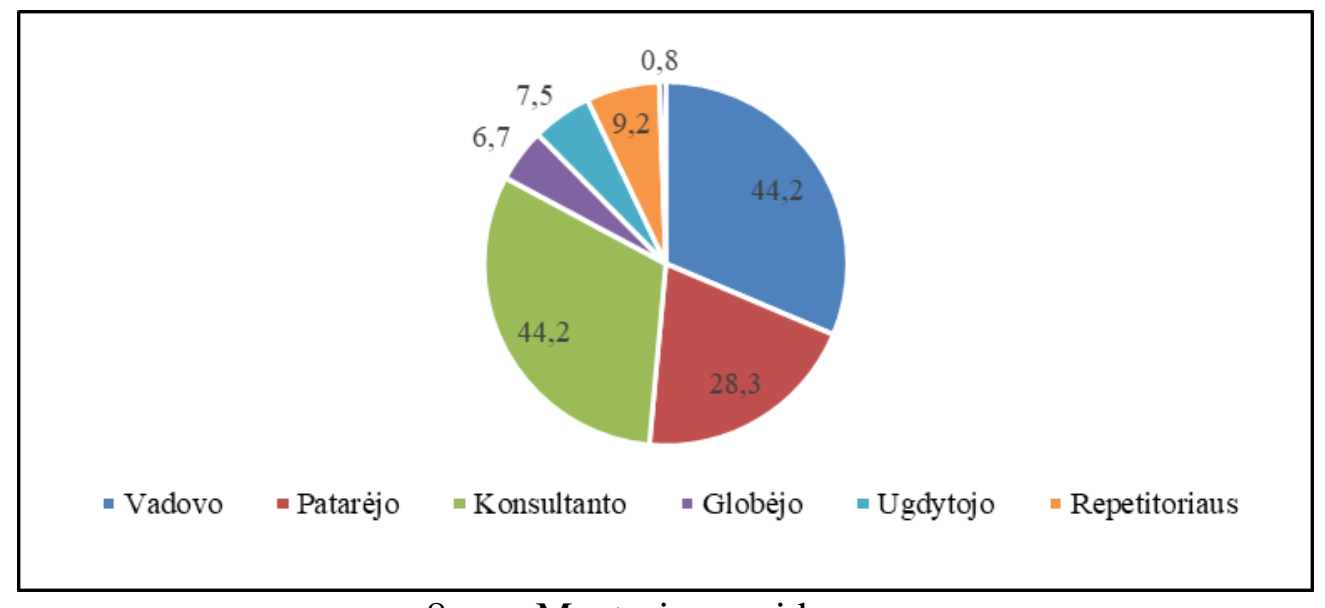

8 pav. Mentoriaus vaidmuo

Šaltinis: sudarytas autorių pagal atlikto tyrimo duomenis

Net 76,7 proc. respondentų išskyrè repetitoriavimo funkciją, padedant naujiems pareigūnams pritaikyti savo teorines žinias praktikoje, kaip svarbiausią (9 pav.).

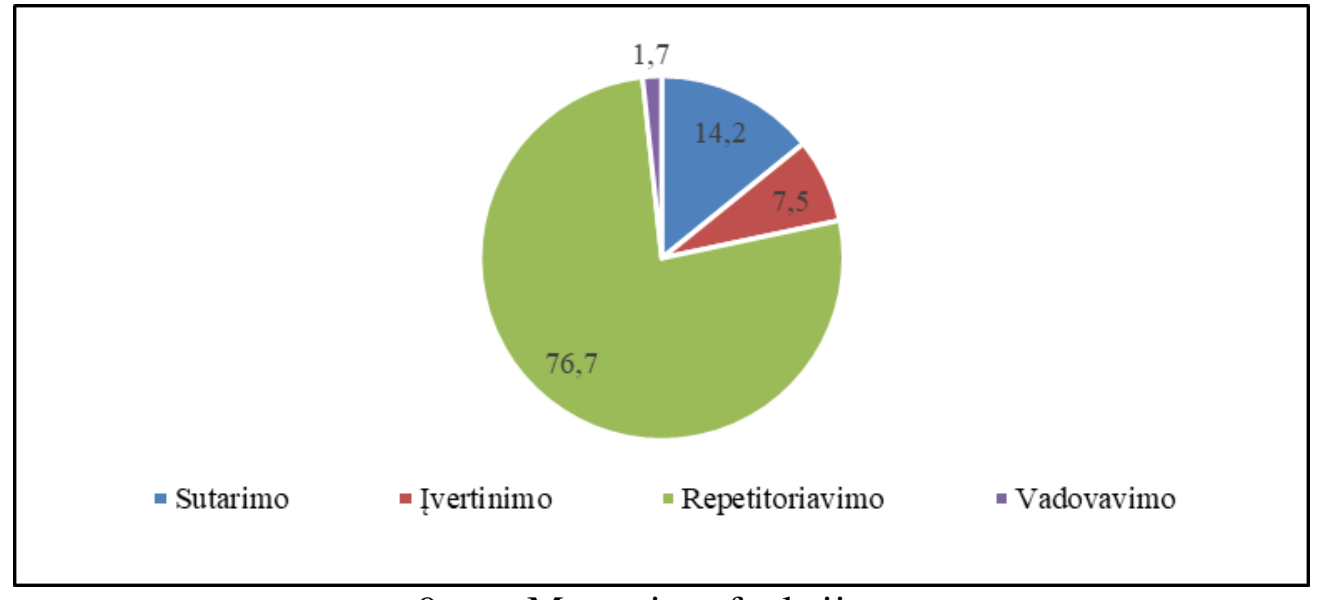

9 pav. Mentoriaus funkcijos

Šaltinis: sudarytas autoriu pagal atlikto tyrimo duomenis

Analizuojant respondentų, atsakiusių $\mathfrak{i}$ abu klausimus, atsakymus, nustatyta, kad nei vienas respondentas, turejęs formalaus mentoriavimo patirties, nepasirinko neformalaus trumpalaikio santykiu lygmens. 76,5 proc. (pasirinkusiu atsakymą Taip, buvau tiesioginiu praktikos vadovu), 100,0 proc. (pasirinkusiu atsakymą Taip, buvau bendruoju praktikos vadovu) ir 76,9 proc. respondentu (pasirinkusių atsakymą Taip, buvau pradedančio ar keičiančio tarnyba pareigūno kuratorius) sutinka su teiginiu, jog mentoriaus darbas turi apimti formalų struktūrizuotą trumpalaikị arba ilgalaikị santykių lygmenị. Neformalų trumpalaikị arba formalų, labai struktūrizuotą, tačiau taip pat trumpalaiki lygmenic, rinkosi tie respondentai, kurie atsakè neturèję mentoriavimo patirties, pagalbą teikè neformaliai arba buvo kursanto kuratoriumi. Vadinasi, galima daryti prielaidą: kuo daugiau igyjama formalios mentorystès patirties, tuo labiau siekiama formalesnių ir labiau struktūrizuotų santykių lygmens.

I mentoriavimo perspektyvas pesimistiškai žvelgia tik 5 proc. respondentų (10 pav.). 


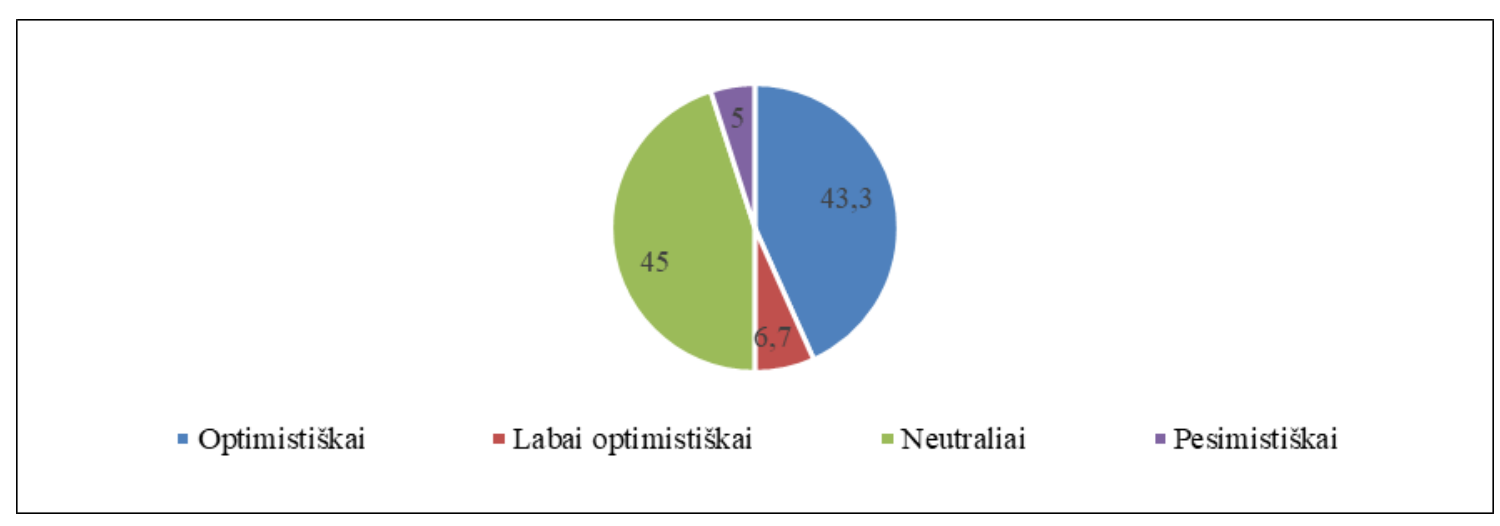

10 pav. Respondentų požiūris ị mentoriavimo perspektyvą

Šaltinis: sudarytas autorių pagal atlikto tyrimo duomenis

Atlikus kintamujų Ar tikslingas mentoriaus pareigybès įvedimas? ir Kaip žiürite ì mentoriavimo perspektyvas Lietuvoje? koreliacinę analizę, nustatyta tiesioginė koreliacija. Kadangi p=0,013<0,05, tarp kintamujų yra statistiškai reikšmingas ryšys. Spearman'o koreliacijos koeficientas lygus 0,226 ryšys tarp kintamujų yra silpnas $\left(\chi^{2}=12,558 ; d f=6 ; p=0,051\right)$. Analizuojant respondentų, atsakiusių $i$ abu klausimus, atsakymus nustatyta, kad 60,3 proc. respondentų, pasisakančių už mentoriaus pareigybès įvedimą, teigiamai vertina mentoriavimo perspektyvas Lietuvoje. Galima daryti prielaidą, jog didèjant optimizmui mentoriavimo perspektyvos atžvilgiu, labiau pritariama mentoriaus pareigybės ịvedimui.

Atlikus kintamuju $\mathrm{Ka}$ manote apie mentoriaus indèli? ir Kaip žiūrite $\dot{l}$ mentoriavimo perspektyvas Lietuvoje koreliacinę analizę, nustatyta tiesioginè koreliacija. Kadangi $\mathrm{p}=0,000<0,05$, tarp kintamujų yra statistiškai reikšmingas ryšys. Spearman'o koreliacijos koeficientas lygus 0,393 ryšys tarp kintamujų yra silpnas $\left(\chi^{2}=44,323 ; \mathrm{df}=12 ; \mathrm{p}=0,000\right)$. nalizuojant respondentų, atsakiusių $\mathrm{i}$ abu klausimus, atsakymus, nustatyta, jog net 67,8 proc. $\mathfrak{i}$ mentoriavimo perspektyvas Lietuvoje optimistiškai arba labai optimistiškai žvelgiančių respondentų mentoriaus indèlį laiko labai svarbiu. Kadangi kuo daugiau svarbos suteikiama mentoriaus indèliui, tuo optimistiškiau žvelgiama i mentoriavimo perspektyvą, todèl galima daryti prielaidą, jog mentoriaus indèlis teigiamai siejamas su formalios mentorystès poreikiu.

Atlikus kintamujų Kaip žiūrite $\grave{l}$ mentoriavimo perspektyvas Lietuvoje ir Mentoriu skaičius koreliacinę analizę, nustatyta tiesioginè koreliacija. Kadangi $\mathrm{p}=0,002<0,01$, tarp kintamujų yra statistiškai reikšmingas ryšys. Spearman'o koreliacjos koeficientas lygus 0,277 - ryšys tarp kintamuju yra silpnas $\left(\chi^{2}=15,557 ; \mathrm{df}=6 ; \mathrm{p}=0,016\right)$. Analizuojant respondentų, atsakiusių $\mathfrak{i}$ abu klausimus, atsakymus, nustatyta, kad tik 15,4 proc. i mentoriavimo perspektyvas Lietuvoje optimistiškai arba labai optimistiškai žvelgiančių respondentų sutinka su teiginiu, jog mentorių skaičius yra pakankamas. Darytina prielaida, jog kuo daugiau svarbos suteikiama mentoriaus indèliui, tuo labiau pasigendama mentorių. Sutinkantys su teiginiu arba nežinantys, ar skaičius yra pakankamas, pesimistiškiau vertina mentoriavimo perspektyvas Lietuvoje. Galima daryti prielaidą, kad teigiamas požiūris ị optimistišką mentoriavimo perspektyvą siejamas su mentorystès plètra (mentorių skaičiaus didinimu) ateityje. Respondentų nuomone, šiuo metu mentorystė Lietuvos policijos mokykloje yra labiausiai orientuota i informavimo ir veiklos palengvinimo aspektus. Pastebètina, jog vertindami mentoriaus elgseną, respondentai taip pat išskyrè informavimą $-41,6$ proc.

Atsakydami i atvirą klausimą Kokia pagalba teikète proteguojamam asmeniui?, 18 proc. respondentų atsakè, kad nebuvo formaliai paskirti praktikos vadovu ar kuratoriumi arba neformaliai neteikè pagalbos. 9 proc. pagalbą teikusiujų kaip svarbiausią nurodè konsultacijas, diskusijas ir individualius pokalbius, 10 proc. - teorinių žinių pritaikymą praktinèje veikloje. Tik 4 proc. teikè pagalbą ịsiliejant i kolektyvą, o 8 proc. savo pagalbą įvardino kaip visapusisišką, dalykinę ir visuomeninę: teikiau visokeriopa pagalba: nuo supažindinimo su kolektyvo nariais, aptarnaujama teritorija iki sudetingu veiksmu atlikimo; nuo asmeniniu iki ivairiausiu problemu sprendimo; nuo kasdienès veiklos užkulisiu iki praktiniu gyvenimišku patarimu bei kasdienès praktinès veiklos kartu su kuruojaтиоju - ne deklaratyvios, o realios ir kt. 
Atsakydami ị klausimą Kokia parama mentorystès procese teike Lietuvos policijos mokykla?, 10 proc. respondentų atsakè, kad mentorystès procese nedalyvavo, 8 proc. - kad negavo jokios pagalbos, kad paskyre mentoriu ir tiek ir kt. 5 proc. teigè, kad pagalba buvo visapusiška. I klausimą Kokia parama mentorystès procese galetu teikti Lietuvos policijos mokykla?, 11 proc. respondentu atsakè nežinau. Kad pagalba turètų būti visapusiška teigè tik 3 proc. tiriamųjų. Kad reikalinga finansinė pagalba ar materialinès priemonès paminejo tik 2 proc. respondentų, pagalba adaptuojantis naujame kolektyve -1 proc., teisinè pagalba -3 proc. Keli respondentai pasiūlè sudaryti galimybes dirbti kartu su didžiausia patirti turinčiais kolegomis, tinkamai parinkti ir paskirti mentoriu, o ne tik formaliai, kontroliuoti mentoriaus veikla, apmokyti mentorius ir juos paruošti , skirti tam laiko darbo metu, o ne po darbo valandu, daugiau demesio skirti mentorystei ir kt. Susidomèjimą sukèlè tiriamojo atsakymas: Visi užsiemę savo funkciju ir uždaviniu vykdymu. Apie kokia parama kalbame? Kiek reikia, tiek padeda, tačiau reikia kreiptis ir, jeigu tai motyvuota, bus suteikta, kuris pagrindžia tiek teorinio, tiek empirinio tyrimų nuostatas, jog reikalinga mentorių atranka ir ne kiekvienas paskirtas patyręs pareigūnas gali juo būti.

Atsakydami ị klausimą Kokia pagalba gavote iš mentoriaus?, 18 proc. apklausos dalyvių teigè, kad negavo pagalbos iš paskirto mentoriaus arba ji buvo neefektyvi, nenaudinga, formali: Ne visi paskirti mentoriai buvo kompetentingi atlikti jiems pavestas funkcijas, todèl tinkamos pagalbos nevisada sulaukdavau ir kt. 11 proc. respondentų teigia, kad iš paskirto mentoriaus gavo labai naudingos pagalbos: Suteike labai aiškia vizija tolimesniam darbui per asmenini pavyzdi (realiu darbu realioje aplinkoje), iš kurios vertingiausia buvo pagrịsta asmeniniu pavyzdžiu ir elgesiu konkrečiose praktinèse situacijose, Pirmiausia gavau saugumo jausma, nes jeigu ko nors nežinojau, tai visada galejau pasiklausti) ir kt.

Teikdami pastabas ir pasiūlymus, respondentai pripažino, kad kiekviename padalinyje turètų būti tinkamai parengtas mentorius. Akcentavo, kad reikalingas didesnis dèmesys patiems mentoriams, jų atrankai, mokymams: Turi tinkamai parinkti ir priskirti pagal asmenybiu suderinamuma kompetentinga mentoriu, taip pat kontroliuoti jo veikla ir kt. Pagrindinę problemą nurodé, kad šiuo metu mentoriaus veikla daugiau formali, nei teikianti naudą. Kai kuriuose atsakymuose atsispindejjo neigiamas požiūris ị mentorystę, prilyginant ją dar vienai formaliai reformai, ir nesugebėjimas susieti jau vykstančių procesų su mentorystès taikymu: Suprantu kuratoriaus kompetencija, tačiau mentoriaus - ne. Dauguma respondentų pastebèjo, kad ne visi gali būti mentoriais ir prieš žadant juo büti, siūlyčiau pirma gerai pagalvoti, geras mokytojas, turintis vadovo, psichologo savybiu, komunikabilus, sugebantis rasti priejima prie ivairaus charakterio asmenu, tikrai sugebès tinkamai tarnybai paruošti nauja pareigūna, suteikti teoriniu ir praktiniu žiniu, motyvacijos dirbti ṣ̌ darba ir kt. Savo siūlymuose jie akcentavo, jog labai svarbu, kad mentorius tikètu savo darbu ir nuoširdžiai tai darytu - ne iš pareigos ar atlygio, o iš paskatos - Ginti, Saugoti, Padèti. Išskyrè ir reikalingas proteguojamo asmens savybes: Svarbu ir tai, kad naujai i tarnyba priimtas pareigūnas suvoktu šiq pagalba, norètu gauti žiniu, norètu mokytis, turèty pats büti motyvuotas, nes ne visi nori mokytis, tobulèti ir dirbti, tačiau visi nori didesnio atlyginimo ir kt.

Taigi iš respondentų atsakymų $\mathfrak{i}$ atvirus klausimus analizès ryškèja, jog tinkamai parinktas mentorius, nuolatinis dėmesys, palaikymas, klaidų analizė ir ịvertinimas yra raktas ị sẻkmingą jauno pareigūno adaptaciją ir tinkamą turimų teorinių žinių pritaikymą praktikoje.

Apibendrinant pagrindinių empirinių duomenų analizę, galima teigti, kad tyrimas atskleidé respondentų požiūrị i tarnybą, darbo aplinką, motyvacines priemones ir mentorystès raišką bei perspektyvą. Pasitvirtino, jog šios sritys itin susijusios. Respondentų požiūris turi tiesioginès įtakos mentorystės perspektyvai Lietuvos policijos mokykloje. Respondentai perspektyvoje tikisi mentorystès proceso, atitinkančio šiuolaikinio mentoriaus veiklą, nes proceso orientavimo aspektus sieja su mentoriaus veiklos aspektais. Kaip svarbiausias išskirtas informavimo aspektas. Nors respondentai optimistiškai žvelgia ị mentorystès perspektyvą Lietuvos policijos mokykloje, tačiau didelè dalis jų nuogąstauja dèl galimai padidèsiančio darbo krūvio. Tai leidžia teigti, kad Lietuvos policijos mokykloje nepakankamai žinoma apie mentorystės teikiamą naudą. 


\section{Išvados}

1. Mentorystès ir mentoriaus samprata profesinès veiklos, Lietuvos policijos mokyklos veiklos kontekste yra pagrịsta teoriškai (formalus, neformalus mentorystès pobūdis) ir priimtina praktiškai kaip parama, pagalba mažiau patirties turintiems pareigūnams (proteguojamiems asmenims), vystant savo karjerą. Mentoriavimas - tai mentoriaus veikla, apibūdinama kaip santykis, ryšys tarp patyrusio ir mažiau patyrusio pareigūno, kurio metu mentorius pamoko, pataria, pagelbsti ir teikia grịžtamajị ryšį. Mentoriaus veikla turi būti grịsta konsultavimo, vadovavimo, stebejjimo, ịvertinimo, sutarimo funkcijomis. Mentorius turi pasižymèti būtinais gebèjimais: būti kompetentingu, pagarbiu, lanksčiu, pasitikinčiu savimi ir proteguojamu asmeniu, suinteresuotu padėti, būti tikru autoritetu ir pavyzdžiu. Skiriamos socialinè, didaktinè, dalykinè ir asmeninè mentoriaus kompetencijos. Mentorystė siejama su kitomis profesinès paramos, pagalbos sritimis: ugdomuoju vadovavimu, supervizija, darbuotojų mokymu ir kt., kuriose vadovaujamasi panašiais principais. Kuri iš šių priemonių naudingesné pareigūnams ir organizacijai, gali spręsti tik pati Lietuvos policijos mokykla.

2. Kiekybiniu tyrimu ištyrus mentoriaus veiklos kompetencijas, respondentai pabrèžia asmeninių savybių svarbą. Pagrindinès asmeninès savybès, kuriomis turi pasižymèti mentorius, yra komunikabilumas, lankstumas, vadovavimo gebejjimai, gebejjimas būti tikru pavyzdžiu proteguojamam asmeniui. Visų šių savybių pritaikymas sudaro galimybę bendradarbiauti mentoriui ir proteguojamam asmeniui. Pagrindinès mentoriaus veiklos funkcijos Lietuvos policijos mokykloje yra parama, pagalba proteguojamam asmeniui, tobulejjant profesinejje veikloje, užtikrinant profesinę integraciją. Lietuvos policijos mokyklai mentorystė gali teikti ne tik didelę naudą žmogiškųjų išteklių vystymo, bet ir žinių vadybos prasme. Taip pat mentorystė teikia naudą ne tik organizacijai ar proteguojamam asmeniui tobulëjant profesinejje veikloje, bet ir pačiam mentoriui. Tyrimu atskleista, jog Lietuvos policijos mokykloje įmanoma igyvendinti formalią mentorystę, nes vyrauja pozityvus požiūris ir yra žmonių, kurie geba bei pageidauja tapti mentoriais. Tyrimas išryškino, jog mentorystė Lietuvos policijos mokykloje orientuota ị informavimą, santykių vystymą bei proteguojamo asmens viziją yra tobulintina mentoriaus veiklos sritis bei elgsena. Mentorystė, orientuota $\mathfrak{i}$ veiklos palengvinimą ir santykių reguliavimą bei veiklos modeliavimą, gali būti tobulintina, bet nèra prioritetinè tirtos organizacijos mentoriaus veiklos sritis ir elgsena.

\section{Literatūra}

1. Benson, P. L., Scales, P. C., Hamilton, S. F. ir Semsa, A., Jr. (2012). Positive development: Theory, research, and applications. In R. M. Lerner (Ed.). Theoretical Models of Human Development. Volume 1 of Handbook of Psychology (6th ed.) (pp. 894- 941). Editors-in-chief: W. Damon \& R. M. Lerner. Hoboken, NJ: Wiley.

2. Bekešienè, S. (2015). Duomeny analizess SPSS pagrindai. Vilnius: Generolo Jono Žemaičio Lietuvos karo akademija.

3. Cloud, H. ir Townsend, J. (2013). Ribos. Kada sakyti „taip“, kaip sakyti „ne“, kad patys tvarkytumete savo gyvenima. Vilnius: AB „Spauda“.

4. Duck, S. (2014). Stratagems, spoils, and a serpent's tooth: On the delights and dilemas of personal relationships. In W. R. Cupach, B. H. Spitzberg (Eds.). The Dark Side of Interpersonal Communication (pp. 3 - 24). Hillsdale, NJ: Lawrence Erlbaum.

5. Elliot, D. S. ir Mihalic, S. (2014). Issues in disseminating and replicating effective prevention programs. Prevention Science, 5, 47 - 3.

6. Erich, L. E., Hansford, B. ir Tennet, L. (2014). Formal mentoring programs in education and other professions: a review of literature. Educational Administration Quarterly, 40, 518-539.

7. Green, M. ir Scholes, M. (2014). Attachment and Human Survival. New York: Karnac.

8. Guay, M. M. (2012). Quelques précisions... le mentorat versus le coaching. Revue Échange, vol.16, no 3 , p. $7-8$.

9. Hawkins, P. (2013). Coaching, Mentoring and Organizational Consultancy: Supervision, Skills and Development. Open University Press; Édition 2. 
10. Hezleet, S. A. ir Gibson, S. K. (2015). Mentoring and human resource development: where we are and where we need to go. Advances in Developing Human Resources, 7, 446-469.

11. Houde, R. (2010). Des mentors pour la relève: Édition revue et augmentée. Le transfert intergénérationnel des connaissances. Revue Télescope, vol. 16, no 1, hiver. ENAP. Québec : PUQ.

12. Merrick, L. (2014). How Coaching and Mentoring can drive succes in your organization. London: Chronus Corporation.

13. Petrin, R. D. (2013). Mentoring: A Business Strategy That Works. Kindle Editon.

14. Petrin, R. D. (2014). Mentoring Readiness Instrument for Mentorees. Kindle Editon.

15. Rhodes, J. E., Reddy, R., Roffman, J. ir Grossman, J. B. (2015). Promoting successful mentoring relationships: A preliminary screening questionnaire. Journal of Primary Prevention, 26(2), 147167.

16. Shea, G. F. (2013). The Mentoring Organization. Crisp Publications.

17. Vileikienè, E. (2018). Policijos darbuotoju motyvacijos tyrimas. VRM.

\section{REALITIES AND PERSPECTIVES OF MENTOR ACTIVITY EXPRESSION: CASE STUDY OF LITHUANIAN POLICE SCHOOL}

Tomas Lukošius, Lithuanian Police School, dr. Gitana Tolutienė, Klaipeda university

Summary

In the analysis of the need for continuing vocational education and training, the problem of activity was observed: officials fail to convey the available professional knowledge and skills by training newly recruited officials on the spot, which superimposed the scientific problem: what are the possibilities of expressing the mentor's activities in the territorial police establishment?

Object: mentoring at the Lithuania police school.

Purpose: to analyze theoretically the activities of the mentor and to empirically reveal the possibilities of expression of mentoring in the Lithuania police school.

Tasks to achieve the purpose of the article: 1) describe the concept of mentoring and mentor, and describe the forms of mentoring, o reveal the peculiarities of the mentor's activity, required characteristics and activity functions in the Lithuanian Police School; 2) to analyze the respondents' attitudes towards the realities and perspectives of the expression of the mentor's activity in the Lithuanian Police School.

The analysis of scientific literature was done in order to theoretically describe and systematize and analyze the concept of mentoring and mentor in the context of a Lithuania police school.

A questionnaire survey was conducted in order to examine the respondents' attitude to the importance of mentoring in the Lithuanian Police School, to reveal the role of the mentor and his / her behavioral attitudes in the Lithuanian Police School. Data analysis is performed by collecting and organizing data using the Google Forms tool to create databases in MS Excel. The obtained results and data are interpreted using specialized statistical computer software SPSS (Social Sciences Statistics Package).

The conclusions of the research: The concept of mentoring and mentoring in the context of professional activity, Lithuanian police school activity is based theoretically (formal, informal nature of mentoring) and acceptable in practice as support, assistance to less experienced officers (protected persons) in developing their career. Mentoring is a mentor's activity, defined as the relationship, the relationship between an experienced and a less experienced officer, during which the mentor teaches, advises, helps and provides feedback. The mentor's activities must be based on the functions of counseling, guidance, monitoring, evaluation, and consensus. The mentor must have the necessary skills: to be competent, respectful, flexible, self-confident and patronized, interested in helping, to be a real authority and example. Social, didactic, subject and personal mentor competencies are distinguished. Mentoring is associated with other areas of professional support and assistance: educational guidance, supervision, staff training, etc., which follow similar principles. Only the Lithuanian Police School itself can decide which of these measures is more useful for officers and the organization.

After examining the competencies of a mentor's activity through quantitative research, the respondents emphasize the importance of personal qualities. The main personal qualities that a mentor should have are communicability, flexibility, leadership skills, the ability to be a real role model for the person being protected. The application of all these qualities provides an opportunity for collaboration between the mentor and the protected person. The main functions of a mentor's activity at the Lithuanian Police School are support, assistance to the protected person, development in professional activities, ensuring professional integration. Mentoring can provide the Lithuanian Police School not only with great benefits in terms of human resource development, but also in terms of knowledge management. Mentoring also benefits not only the professional development of the organization or the mentee, but also the mentor himself. The research revealed that it is possible to implement formal mentoring in a Lithuanian police school, because a positive attitude prevails 
and there are people who are able and willing to become mentors. The research highlighted that mentoring in the Lithuanian Police School focused on information, relationship development and the vision of the protected person is an area of the mentor's activity and behavior that needs to be improved.

Keywords: mentoring, mentor, person protected, Lithuania police school. 